\title{
Peningkatan Membaca Permulaan Melalui Media Flash Card pada Siswa Kelas Rendah Sekolah Dasar
}

\author{
Rahmah Kumullah ${ }^{1}$, Ahmad Yulianto ${ }^{2}$, Ida $^{3}$ \\ STKIP Andi Matappa ${ }^{1}$, Universitas Muhammadiyah Sorong ${ }^{2}$, Guru SD Inpres Paccerakkang \\ rahmahkumullah71@gmail.com
}

\begin{abstract}
Abstrak: Penelitian ini bertujuan untuk meningkatkan proses dan keterampilan membaca permulaan melalui penggunaan media flash card pada siswa kelas I SD Inpres Paccerakkang Kota Makassar. Jenis penelitian ini merupakan penelitian Penelitian Tindakan Kelas (PTK). Subjek penelitian ini adalah siswa kelas I SD Inpres Paccerakkang sebanyak 29 siswa. Objek penelitian adalah peningkatan keterampilan membaca permulaan. Penelitian ini dilakukan dalam dua siklus dengan setiap siklus terdiri dari dua pertemuan. Teknik pengumpulan data menggunakan observasi dan tes unjuk kerja keterampilan membaca permulaan. Instrumen penelitian yang digunakan adalah lembar observasi rating scale dan soal tes unjuk kerja. Teknik analisis data menggunakan analisis deskriptif kuantitatif dan deskriptif kualitatif. Hasil penelitian menunjukkan bahwa keterampilan membaca permulaan melalui penggunaan media flash card pada siswa kelas I SD Inpres Paccerakkang mengalami peningkatan dengan baik. Hal ini terbukti dari pencapaian rerata pada pratindakan persentasenya sebesar 41,38\%, pada siklus I meningkat menjadi 58,62\% dan pada siklus II menjadi $82,76 \%$. Hasil observasi aktivitas siswa juga mengalami peningkatan. Pada siklus I sebesar 59,38\% meningkat menjadi $84,37 \%$ pada siklus II. Peningkatan keterampilan membaca permulaan dapat dilihat dari peningkatan rata-rata skor aspek ketepatan, lafal, intonasi, kelancaran dan kejelasan suara. Langkah-langkah penelitian dalam meningkatkan keterampilan membaca permulaan menggunakan media flash card.
\end{abstract}

Kata Kunci : Membaca permulaan, Flash card, Sekolah Dasar

\begin{abstract}
This study aims to improve the process and initial reading skills through the use of flash card media in first grade students of Paccerakkang elementary school. This type of research is a Classroom Action Research (CAR). The subjects of this study were 29th grade students of Paccerakkang elementary school. The object of the research is the improvement of initial reading skills. This research was conducted in two cycles with each cycle consisting of two meetings. The technique of collecting data uses the observation and test performance of initial reading skills. The research instruments used were observation scale rating sheets and performance test questions. Data analysis techniques used quantitative descriptive analysis and qualitative descriptive. The results of the study showed that the initial reading skills through the use of flash card media in class I of Paccerakkang elementary school. This is evident from the average achievement of the pre-action percentage of $41.38 \%$, in the first cycle it increased to $58.62 \%$ and in the second cycle to $82.76 \%$. The results of observation of student activities also increased. In the first cycle, $59.38 \%$ increased to $84.37 \%$ in the second cycle. Improved initial reading skills can be seen from the increase in the average score aspects of accuracy, pronunciation, intonation, fluency and sound clarity. Research steps in improving initial reading skills using flash card media.
\end{abstract}

Keywords: Read the beginning, Flash card, Elementary School 


\section{Pendahuluan}

Pendidikan merupakan usaha sadar untuk peningkatan kualitas Sumber Daya Manusia (SDM). Kemajuan suatu negara atau bangsa sangat ditentukan oleh pelaksanaan pendidikan (proses pendidikan) di negara tersebut. Oleh karena itu, pendidikan merupakan suatu bidang yang harus diutamakan. Salah satu faktor penting yang mendukung peningkatan kualitas pendidikan adalah kegiatan membaca. Membaca adalah suatu cara untuk mendapatkan informasi dari sesuatu yang ditulis. Seperti hasil penelitian dari Chapman,dkk (2010) yang menunjukkan bahwa kemampuan membaca menjadi prediktor kuat untuk konsep diri yang positif dan negatif di bidang akademik.

Membaca dan mendengar adalah dua cara yang paling umum untuk mendapatkan informasi. Informasi yang didapat dari membaca dapat termasuk hiburan maupun pengetahuan. Kebiasaan membaca sangat baik sejak siswa masih usia dini. Kebiasaan membaca bukan lagi suatu kebiasaan tetapi akan menjadi suatu kebutuhan. Membaca permulaan merupakan tahapan proses belajar membaca bagi siswa sekolah dasar kelas awal. Siswa belajar untuk memperoleh kemampuan dan menguasai tekhnik-tekhnik membaca dan mampu menangkap isi bacaan dengan baik. Keterampilan membaca secara langsung berkaitan erat dengan seluruh proses belajar di sekolah dasar. Keberhasilan siswa dalam mengikuti proses pembelajaran sangat ditentukan oleh penguasaan kemampuan membaca mereka. Siswa yang tidak mampu/masih kurang pandai membaca akan mengalami kesulitan dalam mengikuti kegiatan pembelajaran pada setiap bidang studi. Siswa akan mengalami kesulitan dalam menangkap dan memahami materi yang diberikan dalam berbagai buku pelajaran. Tentu saja akan berpengaruh pada kemajuan prestasi akademiknya.

Pembelajaran membaca permulaan tujuannya adalah agar siswa memiliki kemampuan memahami dan menyuarakan tulisan dengan intonasi yang wajar, sebagai dasar untuk dapat membaca lanjut (Evans, 2015). Pelaksanaan membaca permulaan di kelas I Sekolah Dasar dilakukan dalam dua tahap, yaitu membaca periode tanpa buku dan membaca dengan menggunakan buku (Abdurrahman, 2012). Pembelajaran membaca tanpa buku dilakukan dengan cara mengajar dengan menggunakan media atau alat peraga selain buku misalnya kartu gambar, kartu huruf, kartu kata dan kartu kalimat. Pembelajaran membaca dengan buku merupakan kegiatan membaca dengan menggunakan buku sebagai bahan pelajaran.

Situasi yang sering dijumpai dilapangan masih terdapat beberapa siswa yang belum mampu membaca dengan lancar. Situasi tersebut membuktikan bahwa pengetahuan membaca siswa masih sangat kurang. Tentu saja menghambat mereka dalam berprestasi di kelasnya. Proses belajar mengajar pun akan menjadi kurang efektif karena pemberian materi oleh guru terhambat. Untuk mengatasi masalah tersebut, tentu peranan guru sangatlah penting terutama kepada para guru yang mengajar di kelas-kelas awal dalam hal ini pada kelas 1. Namun ternyata sebagaian guru terkadang masih kurang memahami perannya. Terkadang guru hanya sekedar melaksanakan apa yang ada dalam kurikulum tanpa mengembangkan kurikulum tersebut menjadi suatu pembelajaran yang menarik dan menyenangkan.

Oleh sebab itu guru perlu melakukan perubahan baik perubahan pada dirinya sendiri maupun maupun perubahan dalam hal tekhnik atau metode pembelajaran yang ia gunakan di kelas. Guru perlu merancang pembelajaran membaca dengan baik sehingga mampu menumbuhkan kebiasaan membaca sebagai kondisi yang menyenangkan. Kondisi belajar sebaiknya dilakukan dengan kondisi yang rileks dan menggembirakan, misalnya dengan melakukan beberapa permainan dalam proses pembelajarannya. Permainan yang dapat 
digunakan misalnya permainan bahasa dalam pembelajaran membaca yang dapat menarik perhatian siswa dalam belajar (Nurseto, 2011). Salah satu bentuk media pembelajaran yang dapat membantu guru dalam proses pembelajaran dan penerapan metode pengajaran adalah dengan menggunakan kartu berseri (flash card). Kartu-kartu berseri tersebut dapat berupa kartu bergambar, kartu huruf, kartu kata atau kartu kalimat. Menurut Sadiman (2012) Flash cards merupakan suatu metode yang dapat membantu dalam upaya peningkatan belajar membaca siswa dengan cara memperlihatkan pada siswa tersebut kata dalam setiap kartu secara cepat ( \pm 1 detik/ kata).

Pelajaran membaca dengan menggunakan flash cards yaitu suatu metode atau cara yang digunakan oleh pendidik atau guru yang memafaatkan kartu-kartu berseri atau bergambar atau kartu-kartu huruf dalam upaya peningkatan belajar membaca siswa (Sukartiningsih, 2014). Sesuai dengan hasil penelitian dari Ruhaena (2008) menyatakan bahwa Media kartu banyak membantu untuk membuat anak belajar sambil bermain dan melakukan eksplorasi dan manipulasi huruf. Kelebihan flashcard Susilana (2012: 95) antara lain mudah dibawah, praktis, gampang diingat, dan menyenangkan.

Penggunaan media flash card dapat dilakukan dengan cara sebagai berikut: (1) Kartukartu yang sudah disusun dipegang setinggi dada dan menghadap ke depan siswa, (2) Cabutlah satu per satu kartu tersebut setelah guru selesai menerangkan, (3) Berikan kartu-kartu yang telah diterangkan tersebut kepada siswa yang duduk di dekat guru. Mintalah siswa untuk mengamati kartu tersebut satu persatu, lalu teruskan kepada siswa yang lain sampai semua siswa kebagian, (4) Jika sajian dengan cara permainan, letakkan kartu-kartu tersebut di dalam sebuah kotak secara acak dan tidak perlu disusun, siapkan siswa yang akan berlomba misalnya tiga orang berdiri sejajar, kemudian guru memberikan perintah, misalnya cari gambar candi hindu, maka siswa berlari menghampiri kotak tersebut untuk mengambil kartu yang bergambar candi hindu yang belakangnya bertuliskan candi hindu.

Adapun beberapa penelitian tedahulu yang sejalan dengan penelitian tersebut adalah (1) Pamungkassari (2018) mengemukakan bahwa media flash card dapat meningkatkan kemampuan membaca permulaan dan juga siswa terlihat lebih aktif dalam pembelajaran setiap siklusnya, (2) Indrayani (2016) keterampilan membaca permulaan melalui penggunaan media flas card pada siswa kelas I SDN Surokarsan 2 Yogyakarta mengalami peningkatan dengan baik, hal ini terbukti pada pratindakan sebesar 41,38\%, pada siklus I meningkat menjadi $58,62 \%$ dan pada siklus II menjadi 82,76\%, (3) Janawati, dkk (2013) dengan menggunakan flashcard mampu meningkatkan kemampuan membaca. Hasil penelitian ini menguatkan pendapat Levy, dkk (2005) bahwa pola perkembangan kemampuan membaca sesuai dengan perkembangan usia anak.

Berdasarkan permasalahan yang ada dan solusi yang diambil, maka dilakukanlah penelitian dengan peningkatan membaca permulaan melalui media flash card pada siswa kelas rendah sekolah dasar.

\section{Metode Penelitian}

Pendekatan dalam penelitian ini adalah pendekatan kuantitatif dan pendekatan kualitatif. Dalam penelitian ini data yang diperoleh berupa data dalam bentuk angka dan data dalam bentuk kata kata yang diperoleh melalui tes dan observasi. Hasil tes dianalisis secara deskriptif kuantitatif, sedangkan data hasil observasi dianalisis secara deskriptif kualitatif.

Jenis penelitian ini merupakan penelitian Penelitian Tindakan Kelas yang bertujuan untuk meningkatkan proses pembelajaran membaca permulaan dan meningkatkan 
keterampilan membaca permulaan. Subjek penelitian ini adalah siswa kelas I SD Inpres Paccerakkang Kota Makassar sebanyak 29 siswa. Objek penelitian ini adalah peningkatan keterampilan membaca permulaan. Penelitian ini dilakukan dalam dua siklus dengan setiap siklus terdiri dari dua pertemuan.

Teknik pengumpulan data menggunakan observasi dan tes unjuk kerja keterampilan membaca permulaan. Instrumen penelitian yang digunakan adalah lembar observasi rating scale dan soal tes unjuk kerja. Teknik analisis data menggunakan analisis deskriptif kuantitatif dan deskriptif kualitatif.

\section{Hasil dan Pembahasan}

Berdasarkan hasil penelitian yang telah dilakukan di SD Inpres Paccerakkang, maka diperoleh data-data untuk mengetahui tujuan yang ingin dicapai, yaitu meningkatkan keterampilan membaca permulaan siswa kelas I. Deskripsi data dalam penelitian ini merupakan perbandingan skor yang diperoleh siswa dalam kemampuan membaca permulaan pada saat pratindakan dengan skor yang diperoleh dari hasil penelitian yaitu pada siklus I dan siklus II. Penelitian dikatakan berhasil apabila dari data tersebut terjadi peningkatan yaitu $75 \%$ siswa memiliki nilai di atas 80 .

Pada saat pengambilan data awal, guru melakukan tes unjuk kerja keterampilan membaca permulaan kepada siswa kelas I SD Inpres Paccerakkang. Hal ini dilakukan untuk mengetahui sejauh mana keterampilan membaca permulaan siswa. Siswa maju satu persatu untuk praktik membaca teks sederhana di depan kelas. Dari hasil tes pratindakan tersebut dapat diketahui bahwa sebanyak 58,62\% siswa belum mencapai nilai rata-rata minimal dan sebanyak 41,38\% siswa telah mencapai indikator keberhasilan. Siklus I dilaksanakan dengan dua kali pertemuan begitu pula pada siklus II. Adapun aspek-aspek penilaian membaca permulaan dapat dilihat pada Tabel 1.

Tabel 1. Aspek Penilaian Membaca Permulaan

\begin{tabular}{clccc}
\hline No & Aspek Penilaian & Pra Penelitian & Siklus I & Siklus II \\
\hline 1 & Ketepatan & 11,55 & 14,34 & 16,10 \\
2 & Lafal & 12,1 & 14,41 & 15,84 \\
3 & Intonasi & 12,62 & 15,10 & 15,60 \\
4 & Kelancaran & 12,03 & 15 & 16,24 \\
5 & Kejelasan Suara & 12,68 & 14,24 & 16,10 \\
\hline
\end{tabular}

Banyaknya siswa yang mencapai rerata pada hasil tes unjuk kerja keterampilan membaca permulaan melalui media flash card juga mengalami peningkatan. Peningkatan pada pratindakan, siklus I, dan siklus II dapat digambarkan pada Gambar 1. 


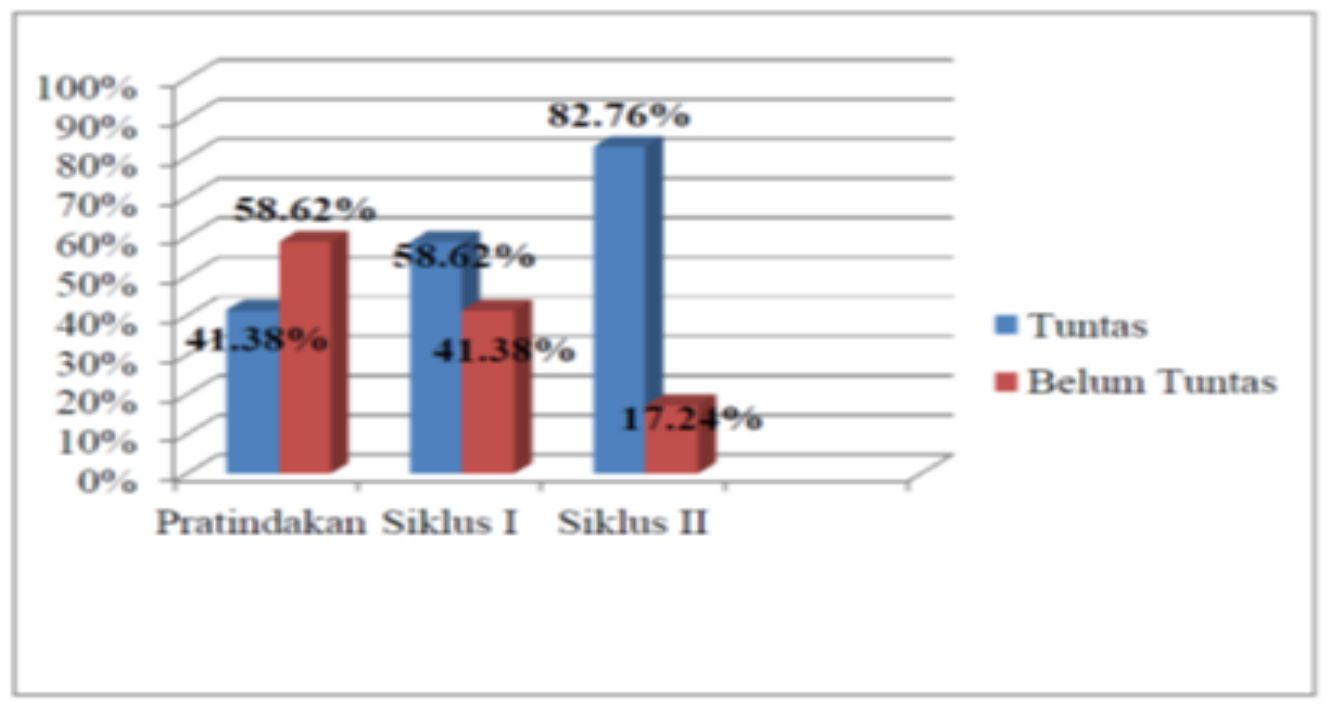

\section{Gambar 1. Diagram batang hasil tes unjuk kerja keterampilan membaca permulaan melalui media flash card}

Berdasarkan diagram batang di atas, dapat diketahui bahwa hasil tes unjuk kerja keterampilan membaca permulaan melalui media flash card rata-rata siswa telah mencapai rerata yang telah ditetapkan yaitu 80 . Pada hasil pratindakan, siswa yang mencapai rerata sebesar $41,38 \%$. Pada siklus I peningkatan banyaknya siswa yang mencapai rerata sebesar $17,24 \%$ dari $41,38 \%$ pada pratindakan menjadi $58,62 \%$ di siklus I. Pada siklus II juga mengalami peningkatan sebesar $24,14 \%$, dari siklus I sebesar $58,62 \%$ meningkat menjadi $82,76 \%$. Dengan demikian hasil dari siklus II ini telah memenuhi kriteria keberhasilan tindakan yang telah ditetapkan.

Perlakuan yang diberikan berupa metode pembelajaran flashcard ini menjadi stimulus untuk belajar membaca anak. Simbol-simbol yang dilihat oleh anak akan di proses ke otak agar dapat dipahami sesuai teori Dorman (2005) karena flash card yang diberikan secara berulang memberikan dampak kepada daya ingat jangka pendek (Short term memory), dan jika terus di ulang-ulang dari daya ingat jangka pendek dapat menjadi daya ingat jangka panjang (Slavin, 2008). Selain itu, flashcard lebih menarik perhatian anak sehingga anak merasa nyaman dan tidak merasa terbebani saat belajar. Oleh karena itu, pemilihan metode pembelajaran menjadi salah satu faktor yang terpenting dalam mempengaruhi kemampuan membaca awal anak seperti yang dikemukakan oleh Somadayo (2011).

Selain metode pembelajaran, menurut Ghabanchi \& Rastegar (2014) kecerdasan (IQ) berhubungan positif dengan membaca, oleh karena itu penulis menggali analisis lebih dalam tentang kemampuan membaca awal anak di lihat dari kecerdasan IQ dan serta adanya eksperimen. Anak yang memiliki kecerdasan yang sangat tinggi memiliki kemampuan membaca awal yang tertinggi. Dapat disimpulkan pengaplikasian media flash card ini memberikan efek besar terhadap kemampuan membaca siswa pada kelas rendah. Metode pembelajaran flashcard sebagai faktor eksternal memiliki dampak lebih besar dari pada kecerdasan sebagai faktor internal. 


\section{Kesimpulan dan Saran}

\section{a. Kesimpulan}

Keberhasilan siswa dalam mengikuti proses pembelajaran sangat ditentukan oleh penguasaan kemampuan membaca mereka. Siswa yang tidak mampu/masih kurang pandai membaca akan mengalami kesulitan dalam mengikuti kegiatan pembelajaran pada setiap bidang studi. Siswa akan mengalami kesulitan dalam menangkap dan memahami materi yang diberikan dalam berbagai buku pelajaran. Tentu saja akan berpengaruh pada kemajuan prestasi akademik, alternatif pembelajaran untuk meningkatkan kemampuan membaca permulaan adalah dengan menggunakan media flash card.

\section{b. Saran}

Bagi peneliti selanjutnya yang tertarik untuk meneliti tentang peningkatan kemampuan membaca permulaan anak dengan flash card, hasil dari penelitian ini dapat dijadikan ide untuk peneliti-peneliti selanjutnya, harapan di penelitian selanjutnya semoga dapat menyempurnakan hasil dari penelitian ini menjadi lebih baik. Misalnya, menggunakan subjek yang lebih besar, pelaksanaan treatment dapat dilakukan secara kontinue setiap hari, dan penyampaian pengajaran dilakukan oleh guru pendidik agar anak didik tidak merasa asing ataupun bias saat memberikan materi pembelajaran.

\section{Daftar Pustaka}

Abdurrahman, M. 2012. Anak Berkesulitan Belajar. Rineka Cipta

Chapman, J. W., Tunmer, W. E., \& Prochnow, J. E. (2010). Early reading-related skills and performance, reading self-concept, and the development of academic self-concept: a longitudinal study. Journal of Educational Psychology. 92 (4), 703 - 708.

Dorman, G. (2005). How To Teach Your Baby to Read. Jakarta: PT. Tigaraksa.

Evans, L J. 2015. Teaching Reading by Machine: A Case History in Early Reading Behavior

Ghabanchi, Z., \& Rastegar, R. (2014). The Correlation of IQ and Emotional Intelegence with Reading. Reading Matrix: An International Online Jurnal, 135-144.

Indrayani, A. O. (2016). Peningkatan Keterampilan Membaca Permulaan Melalui Penggunaan Media Flash Card Siswa Kelas I SDN Surokarsan 2 Yogyakarta. Skripsi. Program Studi Pendidikan Guru Sekolah Dasar Universitas Negeri Yogyakarta.

Janawati, D. P., Sudiana, I. N., \& Dantes, N. (2013). Pengaruh Implementasi Pembelajaran Kartu Kata dalam Permainan Domino Terhadap Peningkatan Kemampuan Membaca Menulis. e-journal Program Pascasarjana Universitas Pendidikan Ganesha. 3 (-) 
Levy, B. A., Gong, Z., Hessels, S., Evans, M.A., \& Jared, D. (2005). Understanding print : Early Reading development and the contribution of home literacy experiences. Experimental Child Psychology, 63-93.

Nurseto, Tejo. (2011). Membuat Media Pembelajaran Yang Menarik. Jurnal Ekonomi dan Pendidikan. 8 (1), 19-35, from doi: https://doi.org/10.21831/jep.v8i1.706

Pamungkassari, W. D. (2018). Peningkatan Kemampuan Membaca Permulaan Melalui Media Flashcard Pada Siswa Kelas I. Jurnal Pendidikan Guru Sekolah Dasar Edisi 7 Tahun ke-7. 669-677.

Ruhaenah, L. (2008). Pengaruh Metode Pembelajaran Jolly Phonics Terhadap Kemampuan Baca-Tulis Permulaan Bahasa Indonesia Dan Bahasa Inggris Pada Anak Prasekolah. Jurnal Penelitian Humaniora. 9 (2), 192-206.

Sadiman, A. (2012). Media Pendidikan: Pengertian, Pengembangan, dan Pemanfaatannya. Jakarta: PT Raja Grafindo Persada

Slavin, R. (2008). Psikologi Pendidikan ( $8^{\text {th }}$ ed). Jakarta: PT. Indeks.

Somadayo, S. (2011). Strategi dan Teknik Pembelajaran Membaca. Yogyakarta: Graha Ilmu.

Surkatiningsih, Wahyu. (2014). Peningkatan Kualitas Pembelajaran Membaca Dan Menulis Permulaan Di Kelas 1 Sekolah Dasar Melalui Media Kata Bergambar. Edustream: Jurnal Pendidikan Dasar. 5 (1).

Susilana, R \& Riyana, C. (2012). Media Pembelajaran. Hakikat, Pengembangan, Pemanfaatan, dan Penilaian. Bandung: CV Wacana Prima. 